\title{
Increased Plasma Arginine Vasopressin in Clinical Adrenocortical Insufficiency and Its Inhibition by Glucosteroids *
}

\author{
Abdul B. J. Ah med, Barbara C. George, Carlos Gonzalez-Auvert, and \\ Joseph F. Dingman † \\ (From the Lahey Clinic Foundation Endocrine Research Unit, Robert B. Brigham Hospital, \\ and the Department of Medicine, Peter Bent Brigham Hospital and Harvard \\ Medical School, Boston, Mass.)
}

\begin{abstract}
Summary. Trichloroacetic acid extracts of plasma were fractionated on a CG-50 resin column and the 50\% acetic acid eluents chromatographed on silicic acid-impregnated glass paper in butanol-acetic acid-water. The specific arginine vasopressin (AVP) zone was eluted and assayed for antidiuretic activity in the diuretic rat. Thioglycolate inactivation was used to confirm AVP activity. Recovery of as little as $4 \mu \mathrm{U}$ AVP per ml plasma ranged between 80 and $90 \%$. In normal subjects after an overnight fast, plasma AVP ranged between 2.5 and $10.0 \mu \mathrm{U}$ per ml. AVP secretion was inhibited by hemodilution and stimulated with nicotine and hypertonic saline. Plasma AVP was absent in patients with diabetes insipidus even after neurohypophyseal stimulation. Plasma AVP was abnormally elevated during mild dehydration and remained above the normal range despite hemodilution in patients with untreated adrenocortical insufficiency demonstrating a delayed water diuresis. Glucosteroid therapy lowered plasma AVP to normal in dehydrated patients. A normal diuretic response to hydration was accompanied by a fall in plasma AVP to zero in steroid-treated patients. These findings suggest that hypersecretion of AVP may play an important role in the abnormal water metabolism of adrenocortical insufficiency and that the glucosteroids promote normal water diuresis by inhibiting the secretion of AVP from the neurohypophysis.
\end{abstract}

\section{Introduction}

Increased or sustained antidiuretic hormone $(\mathrm{ADH})$ secretion has long been implicated in the abnormal water metabolism of primary and secondary adrenocortical insufficiency. The glucosteroids have been shown to correct the abnormal

\footnotetext{
* Submitted for publication February 4, 1966; accepted September 28, 1966.

Supported in part by U. S. Public Health Service grants HE06965 and AM05577.

Dedicated to Dr. George W. Thorn on his sixtieth birthday.

A preliminary report of this work has been published in abstract form (1).

$\dagger$ Address requests for reprints to Dr. Joseph F. Dingman, Peter Bent Brigham Hospital, 721 Huntington Ave., Boston, Mass. 02115.
}

water diuresis of this disorder by increasing the renal excretion of solute-free water (2-4). Raisz, McNeely, Saxon, and Rosenbaum (2) and Kleeman and his co-workers (3) support the view that the glucosteroids have a direct effect on the renal tubules independent of $\mathrm{ADH}$; on the other hand, Dingman and Despointes (4) have shown that the secretory activity of the neurohypophysis is depressed during glucosteroid-induced free water diuresis and postulated that these steroids promote normal water diuresis by inhibiting $\mathrm{ADH}$ secretion.

On the basis of direct antidiuretic bioassays of whole plasma, Kleeman, Czaczkes, and Cutler (5) have recently claimed that there is no abnormality of $\mathrm{ADH}$ secretion in adrenal insufficiency. We 
have studied this problem with an improved method for extraction and purification of arginine vasopressin ${ }^{1}$ from human plasma. Our data demonstrate that sustained hypersecretion of AVP does exist in clinical adrenocortical insufficiency and that the glucosteroids correct the abnormal water diuresis by inhibiting secretion of AVP from the neurohypophysis.

\section{Methods}

Antecubital venous blood is collected without stasis in a heparinized plastic syringe and transferred to a test tube immersed in ice. ${ }^{2}$ Within 5 to 10 minutes of collection, the blood is centrifuged at $4^{\circ} \mathrm{C}$ for 15 minutes at $3,500 \mathrm{rpm}$. The plasma (at least $10 \mathrm{ml}$ ) is extracted with trichloroacetic acid (TCA) as described by Weinstein, Berne, and Sachs (6) except that removal of TCA by extracting the solution with diethyl ether is omitted. ${ }^{3}$ The extract is adjusted to $\mathrm{pH} 4.0 \pm 0.2$ (glass electrode) with dilute $\mathrm{NH}_{4} \mathrm{OH}$.

IRC-50 (XE64) resin 4 ( $\mathrm{H}$ form in $\mathrm{H}_{2} \mathrm{O}$ ) is prepared according to Hirs, Moore, and Stein (8). A resin column $2 \mathrm{~cm}$ in diameter and 1.5 to $2.0 \mathrm{~cm}$ high is cycled at a flow rate of $2 \mathrm{ml}$ per minute with $25 \mathrm{ml}$ water followed by $25 \mathrm{ml} 50 \%$ acetic acid ( $\mathrm{vol} / \mathrm{vol})$ and then additional water until the $\mathrm{pH}$ of the eluent is equal to that of the water. The plasma extract is passed through the column, the column washed with $25 \mathrm{ml}$ water, and the hormone eluted with $25 \mathrm{ml} 50 \%$ acetic acid (9). This acid eluent is collected in a 500-ml round bottom flask and concentrated to approximately $0.5 \mathrm{ml}$ in an all glass rotatory evaporator at $30^{\circ} \mathrm{C}$. The solution is quantitatively transferred to a $50-\mathrm{ml}$ conical test tube with several milliliters of water, evaporated to dryness, and dissolved in $0.25 \mathrm{ml}$ acid alcohol (70\% ethyl alcohol acidified to $\mathrm{pH}$ 3.5 with glacial acetic acid).

Strips of glass fiber paper $55 \times 15$ inches are impregnated with silicic acid (10) and dried in an oven at $100^{\circ}$ $\mathrm{C}$ for 30 minutes immediately before use. The concentrated column eluate is applied as a narrow streak along a transverse line $2.5 \mathrm{~cm}$ from the lower end of a paper sheet. The flask is washed twice with small amounts of acid alcohol, which are also applied to the paper strip. A reference standard of $5 \mu \mathrm{g}$ lysine vasopressin (LVP)

1 Arginine vasopressin has been shown to be the antidiuretic hormone $(\mathrm{ADH})$ of most mammals, including man, and this term will be used synonymously with ADH in this paper.

2 Siliconized glassware is used throughout, and all procedures except concentration of solutions are carried out at $4^{\circ} \mathrm{C}$.

3 We have obtained evidence from recovery of vasopressin added to plasma (7) that as much as $30 \%$ of biological activity may be lost during ether extraction.

${ }^{4} \mathrm{Rohm}$ and Haas, Philadelphia, Pa., now supplied as CG-50 resin.

5 No. 934-AH, H. Reeve Angel, Clifton, N. J. is placed on the origin to one side of the paper and isolated from the rest of the chromatogram by cutting out a wedge of paper between the standard and the unknown. Synthetic lysine vasopressin ${ }^{6}$ and purified natural LVP 7 have identical $R_{r}$ and can be used interchangeably. This material is used as reference standard because of its availability in concentrated form and because of the unavailability of sufficient quantities of AVP concentrates. USP bovine posterior pituitary standard contains only about $0.4 \% \mathrm{AVP}$ and is unsuitable for visual identification of AVP on the paper chromatogram.

Two to 3 inches of the upper end of the paper is immersed in the trough of a descending chromatography chamber. The trough is filled with acetone and the paper washed with $10 \mathrm{ml}$ acetone by descending overflow chromatography at a flow rate of about $2 \mathrm{ml}$ per minute. The vasopressins are insoluble in acetone, and this wash will remove much of the solids that are obtained from some plasmas. The paper is dried in a cool air stream, the lower edge is cut off $1.0 \mathrm{~cm}$ from the origin, and 3 to 5 inches of the upper end is also removed.

The chromatogram is developed by the ascending technic at $4^{\circ} \mathrm{C}$ in a covered glass jar in $n$-butanol 80 , acetic acid 12, water 20 . The precise proportion of solvents may require adjustment, since the $R_{\mathfrak{r}}$ of $L V P$ varies somewhat with different batches of paper. LVP should have an $R_{f}$ of about 0.7 in this system. Preliminary equilibration is not necessary, and the chromatogram develops in approximately 2 hours at this temperature. The chromatogram is dried in a cool air stream. The section containing the LVP standard is cut from the chromatogram and sprayed with Folin's phenol reagent and then with a saturated solution of sodium carbonate, which produces a blue color with tyrosine in the peptide. Since AVP has an $R_{f}$ of approximately 0.4 when the $R_{t}$ of LVP is 0.7 in this system, a section is cut from the chromatogram between $R_{f} 0.3$ and 0.6 to include the entire AVP area (see Results).

The AVP paper segment is eluted with $30 \mathrm{ml}$ acid alcohol by descending overflow chromatography (11) with the rate of flow adjusted to about $3 \mathrm{ml}$ per minute by varying the level of solvent in the jar. This eluent is collected in a $500-\mathrm{ml}$ round bottom flask and evaporated to about 2 to $3 \mathrm{ml}$, and the contents are quantitatively transferred to a small lyophilizing flask and lyophilized to dryness. The dry residue is stored at $-20^{\circ} \mathrm{C}$ until bioassay is performed, at which time the material is dissolved in sufficient $0.25 \%$ acetic acid in Ringer's solution to equal a tenfold concentration of plasma. This solution is stable at $-20^{\circ} \mathrm{C}$ for at least 24 hours.

Antidiuretic assay. Female Sprague-Dawley rats 8 weighing 80 to $120 \mathrm{~g}$ are used for assay. Since rats surgically stressed on the day of study often show prolonged antidiuresis, a catheter is placed in the urinary bladder under general anesthesia 18 to 24 hours before study. The fluted end of a $3-$ to $5-\mathrm{cm}$ length of poly-

\footnotetext{
6 Sandoz Pharmaceuticals, Hanover, N. J.

7 National Institutes of Health Endocrinology Study

${ }^{8}$ Charles River Breeding Laboratories, Boston, Mass.
} Section. 
ethylene tubing ( 0.05 inch o.d.) is positioned over the trigone and the bladder wrapped around the catheter to eliminate dead space. The end of the catheter is cut off close to the anterior abdominal wall.

The rat is fasted overnight but allowed water ad libitum. On the morning of assay, $10 \%$ ethyl alcohol is administered by gavage in a volume equal to $5 \%$ of body weight. Twenty minutes later a similar volume of $5 \%$ alcohol is readministered by gavage through a polyethylene tubing that is left in place. The tip of a no. 23 hypodermic needle attached to a short length of polyethylene tubing ( 0.038 inch o.d.) is inserted into the tail vein with the aid of a needle forceps and the tubing filled with physiological saline and occluded with an ordinary straight pin.

Constant hydration ${ }^{9}$ is maintained by a modification of the apparatus described by Sawyer (12), with $2 \%$ alcohol in $0.2 \%$ saline as the hydrating fluid. The urine flows through a conductivity flow cell 10 and a photoelectric drop counter, both of which are connected to a Grass polygraph for continuous recording.

A suitably prepared animal will attain a rate of urine flow of between 2 and 5 drops per minute (average, 48 drops per $\mathrm{ml}$ ) within a period of 1 to 2 hours. Solutions are injected rapidly through the tail vein catheter during periods of contant urine flow, usually at intervals of 30 to 40 minutes. The catheter is rinsed with Ringer's solution after each injection to make a total volume of injectate of $0.5 \mathrm{ml}$. With antidiuretic activity as the index, the USP $2 \times 2$ method for vasopressin assay (13) is followed. Standard 11 and unknown solutions are administered in the prescribed fashion at two potency levels in a $3: 2$ or $2: 1$ ratio for a total of four injections of standard and four of unknown, and relative potency of the unknown is calculated as described. When there is no antidiuretic response to the larger dose of unknown (usually 0.2 or $0.3 \mathrm{ml}$ plasma extract), a single injection of 0.5 to $1.0 \mathrm{ml}$ is administered, depending on the volume remaining. If this larger dose produces a measurable antidiuretic response, potency of the unknown is calculated from a log dose-response plot of the standards.

When sufficient sample is not available or if the assay animal becomes unsuitable, the assay is completed with at least two doses of standard and two of unknown and unknown potency calculated from a $\log$ dose-response plot of the standards. Antidiuretic activity is calculated as the percentage change in urine flow, comparing the drops per 10 minutes in the interval for -10 to 0

\footnotetext{
${ }^{\circ}$ Since the rats rarely pass urine during the period of preparation, the positive fluid balance is usually equal to $10 \%$ of the body weight. Any urine voided during preparation is ignored at this point.

10 Industrial Instruments, Cedar Grove, N. J.

11 USP bovine posterior pituitary powder is prepared as instructed and stored at $4^{\circ} \mathrm{C}$ in a concentration of $100 \mathrm{mU}$ per $\mathrm{ml}$ in $0.25 \%$ acetic acid. Dilute standard solutions containing 50 to $100 \mu \mathrm{U}$ per $\mathrm{ml}$ are freshly prepared from the stock solution with $0.25 \%$ acetic acid in Ringer's solution as diluent.
}

minutes (control value) with the drops per 10 minutes between +2 and +12 minutes after injection.

The conductivity flow cell is calibrated with $\mathrm{NaCl}$ solutions of known concentration. The constant monitoring of urinary conductivity is useful for determining the optimal periods of water diuresis for injection of samples and for demonstrating the increased urinary conductivity characteristic of AVP antidiuresis.

Thioglycolate inactivation of $A V P$. A $1.0 \mathrm{M}$ stock solution of thioglycolic acid is adjusted to $\mathrm{pH} 7.5$ with $3 \% \mathrm{NaOH}$. A $0.1 \mathrm{M}$ solution is made fresh from the stock solution and added to a sample of the plasma concentrate in a 1:10 ratio to make a $0.01 \mathrm{M}$ sodium thioglycolate solution. The mixture is incubated at room temperature for 30 minutes and assayed for antidiuretic activity.

Experiments on human subjects. Studies were performed on normal laboratory personnel, five patients with idiopathic diabetes insipidus off vasopressin therapy, and eight patients with documented primary or secondary adrenocortical insufficiency receiving appropriate substitution therapy. The subjects abstained from food, fluids, and smoking from 10 p.m the evening before study, except that the patients with diabetes insipidus were allowed free access to water. Urine was collected from 10 p.m. to 6 a.m. and hourly thereafter until water administration. The normal subjects were ambulatory during study, but the patients remained recumbent in bed in the morning except for voiding and body weight measurement. A breakfast of toast, egg, and $90 \mathrm{ml}$ orange juice was given about 7 a.m. A dehydration (control) plasma sample was obtained between 8 a.m. and 9 a.m. after which the subject was hydrated orally with $20 \mathrm{ml}$ water per $\mathrm{kg}$ within a period of 15 to 30 minutes. A "hydration" plasma sample was obtained 90 to $120 \mathrm{~min}$ utes from the start of hydration.

In the standard water tests, voided urine specimens were collected at 30 - to 60 -minute intervals for 4 hours after a single water load. Nicotine stimulation studies were performed during constant hydration, which was maintained after the priming water load by administration of additional water every 15 minutes at a rate equal to urine flow. Nicotine was administered to the normal subjects by having them smoke one or two cigarettes, and a plasma sample was obtained with the onset of antidiuresis. The patients with diabetes insipidus received graded doses of nicotine solution intravenously by a previously described technic (14). A plasma sample was obtained approximately 5 minutes after the administration of the largest dose of nicotine producing significant pharmacological effects (paresthesia, vertigo, nausea, or vomiting). Hypertonic saline $(10 \mathrm{ml} 3 \% \mathrm{NaCl}$ per $\mathrm{kg}$ body weight) was infused rapidly over a 15 - to 30 -minute period during water diuresis after readjustment of the positive water balance to $10 \mathrm{ml}$ per $\mathrm{kg}$. Plasma osmolality was measured just before the infusion and another plasma sample obtained for osmolality and AVP with the onset of antidiuresis or 30 to 45 minutes after termination of the infusion in those patients not demonstrating an antidiuretic response. 
TABLE I

Antidiuretic response of rats to USP bovine posterior pituitary standard $(A V P)^{*}$

\begin{tabular}{|c|c|c|c|c|c|c|c|}
\hline \multirow[b]{2}{*}{ AVP } & \multirow[b]{2}{*}{ Doses } & \multicolumn{2}{|c|}{$\begin{array}{l}\text { Control urine } \\
\text { flow }\end{array}$} & \multicolumn{2}{|c|}{$\begin{array}{l}\text { Per cent re- } \\
\text { duction }\end{array}$} & \multirow[b]{2}{*}{$\mathrm{SD}$} & \multirow[b]{2}{*}{ covt } \\
\hline & & Mean & Range & $\overline{\text { Mean }}$ & Range & & \\
\hline$\mu U$ & & drops/ & $10 \min$ & & & & \\
\hline 2 & 8 & 45.5 & $35-82$ & 8.4 & $0-15$ & 5.7 & 70 \\
\hline 4 & 10 & 40.9 & $26-58$ & 23.3 & $15-37$ & 7.3 & 32 \\
\hline 5 & 11 & 53.6 & $34-88$ & 29.1 & $14-45$ & 9.9 & 34 \\
\hline 10 & 20 & 49.2 & $27-92$ & 47.4 & $30-82$ & 12.7 & 27 \\
\hline 15 & 12 & 46.8 & $20-60$ & 64.8 & $40-87$ & 13.2 & 20 \\
\hline
\end{tabular}

* AVP $=$ arginine vasopressin

t Coefficient of variation.

The effect of glucosteroids in patients with adrenocortical insufficiency was evaluated in two ways. Most patients performed two standard water tests as outlined above, the first one off glucosteroids for 24 to 48 hours and the second one while on regular maintenance therapy and after an oral dose of glucosteroid 2 to 3 hours before hydration. Two patients off glucosteroids for 24 to 48 hours were given a priming water load and maintained in constant hydration by administration of additional water at a rate equal to urine flow. A "hydrated" plasma sample was obtained at peak diuresis, after which $100 \mathrm{mg}$ hydrocortisone was injected intravenously and another plasma sample obtained at the peak of the diuretic response to hydrocortisone. In the latter studies, urine was collected at 15-minute intervals through an indwelling urethral catheter, the patients receiving $300 \mathrm{mg}$ demethylchlorotetracycline by mouth 2 hours before catheterization.
Plasma and urine samples were analyzed for osmolality by cryoscopy, for $\mathrm{Na}$ and $\mathrm{K}$ by flame photometry, and for creatinine by the Jaffe reaction (15).

\section{Results}

\section{AVP standard dose-response curve}

The sensitivity and precision of the bioassay were evaluated by statistical analysis of the antidiuretic responses to AVP standard observed during the actual assay of unknown samples. The responses to 61 injections in 21 rats over the dose range of 2 to $15 \mu \mathrm{U}$ AVP are summarized in Table I. It is apparent that significant variations in basal urine flow were observed among animals, with an extreme range of from 20 to 92 drops per 10 minutes. Similar but less marked changes in basal urine flow were also apparent in individual animals, there being a gradual trend toward higher rates of flow as the assay progressed in time. There was also significant variability among animals in the response to a given dose of AVP, as shown by the standard deviations and coefficients of variation, particularly at the $2-\mu \mathrm{U}$ dose level (Table I). Two $\mu \mathrm{U}$ AVP was in the minimal range of detection of the method with some rats showing no antidiuretic response to this dose.

An arithmetic plot of percentile reduction in urine flow against the logarithm of the dose (Fig-

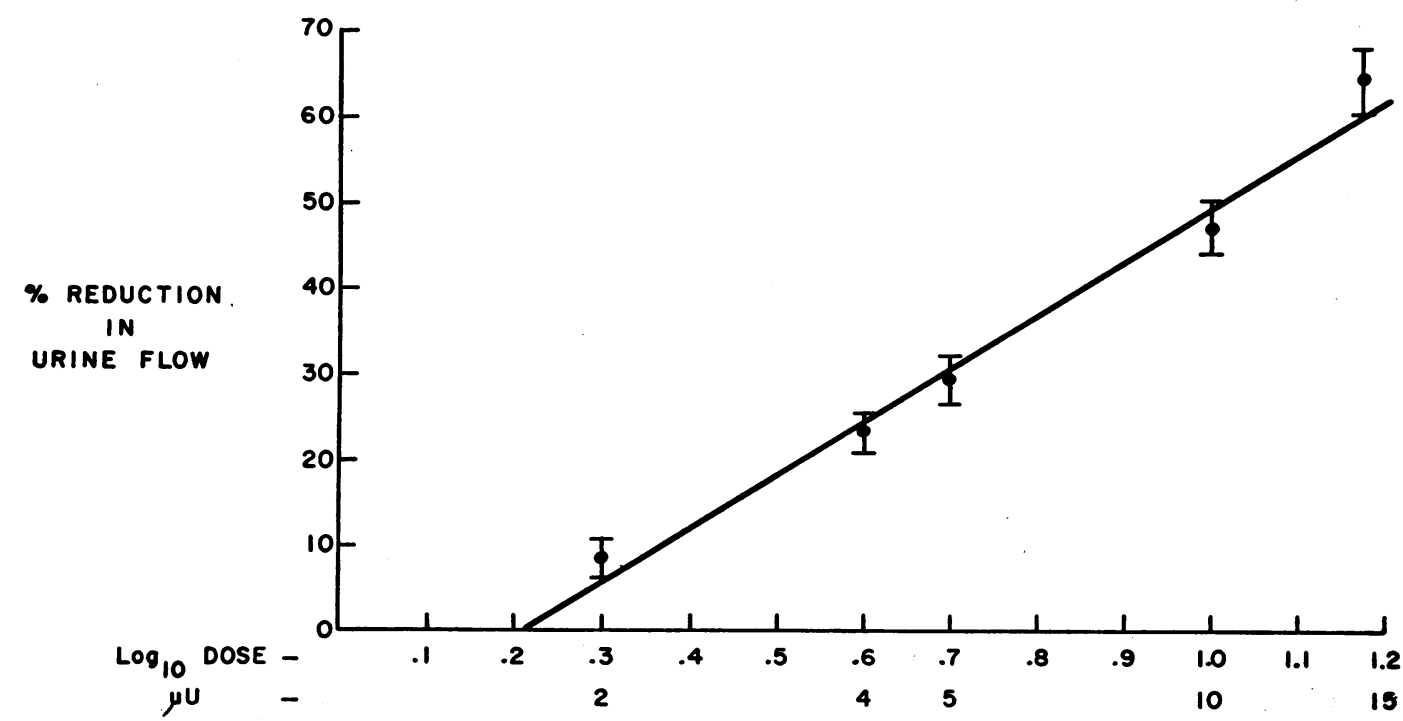

Fig. 1. DOSE RESPONSE to USP POSTERIOR PITUITARY STANDARD (ARGININE VASOPRessin, AVP) IN RATS. The estimating equation for the data is $Y=-13.83+63.47 X(p<0.001)$. The mean \pm standard error of the mean for each dose of AVP is shown. 
ure 1) revealed a statistically significant $(\mathrm{p}<$ 0.001 ) dose-response relationship over the 2- to $15-\mu \mathrm{U}$ range, with an index of precision $(\lambda)$ of 0.08 .

\section{Recovery experiments}

Glass paper chromatography of synthetic AVP. In multiple studies, the $R_{f}$ of synthetic AVP ${ }^{12}$ ( 5 to $10 \mu \mathrm{g}$ ) by spot test was found to average 0.4 when the $R_{f}$ of LVP was approximately 0.7 in this chromatographic system. Five hundred $\mathrm{mU}$ synthetic AVP and $5 \mu \mathrm{g}$ LVP were chromatographed on glass paper as described. After removal of the LVP section, the chromatograms were cut transversely into ten equal segments from origin to front, and each strip was eluted with acid alcohol. The residue was dissolved in acidified Ringer's solution and bioassayed against synthetic AVP standards. In three quantitative experiments, the recovery of AVP averaged $25.6 \%$ between $R_{f} 0.3$ and 0.4 and $63.4 \%$ between $\mathrm{R}_{\mathrm{f}} 0.4$ and 0.5 , for a total recovery of $89 \%$ (range, 81 to $95 \%$ ) between $R_{f} 0.3$ and 0.5 , when the $R_{\mathbf{f}}$ of LVP (spot test) was approximately 0.7 . In two other qualitative studies, bioactivity also was found only between $R_{f} 0.3$ and 0.5 .

12 Kindly supplied by Dr. R. Bircher, Sandoz Pharmaceuticals, Hanover, N. J.
Glass paper chromatography of plasma AVP. Fifteen to $25 \mathrm{ml}$ plasma from three subjects was extracted and chromatographed on CG-50 resin columns as described. The lyophilized column eluates were quantitatively applied to glass paper sheets and chromatographed. Segments of the paper strips were cut out between $R_{f} 0.3$ to 0.4 , 0.4 to 0.5 , and 0.5 to 0.6 , and each segment was eluted and bioassayed as described. The $R_{f} 0.4$ to 0.5 segments showed total antidiuretic activity of 150,192 , and $254 \mu \mathrm{U}$, respectively. The $R_{\mathbf{f}}$ 0.3 to 0.4 segments showed $15 \mu \mathrm{U}$ in the first sample, but the remaining two had no activity. None of the $R_{f} 0.5$ to 0.6 segments showed any bioactivity.

Evaluation of nonspecific antidiuretic activity in method. TCA extracts of six samples of Ringer's solution and seven separate samples of 60-day-old human plasma were cycled through the XE64 resin (experiments 1 and 2, Table II). No antidiuretic activity was found in the acetic acid eluents of these resin columns. However, column eluents of eight other samples of old plasma (experiment $3 \mathrm{a}$, Table II) showed antidiuretic activity averaging $10 \mu \mathrm{U}$ per $\mathrm{ml}$, which could not be inactivated by thioglycolate. Glass paper chromatography of the column eluents of two plasma samples containing this nonspecific

TABLE II

Recovery experiments*

\begin{tabular}{|c|c|c|c|c|c|c|}
\hline \multirow{2}{*}{$\begin{array}{c}\text { Experi- } \\
\text { ment }\end{array}$} & \multirow[b]{2}{*}{ Solution $\dagger$} & \multirow{2}{*}{$\begin{array}{c}\text { No. } \\
\text { samples }\end{array}$} & \multirow{2}{*}{$\begin{array}{l}\text { Column } \\
\text { eluate }\end{array}$} & \multirow{2}{*}{$\begin{array}{c}\text { Paper } \\
\text { chromato- } \\
\text { gram }\end{array}$} & \multicolumn{2}{|r|}{ AVP } \\
\hline & & & & & Added & Recovered \\
\hline & & & & & & $\mu U / m l$ \\
\hline 1. & Ringer's solution & 6 & + & $-\ddagger$ & 0 & 0 \\
\hline 2. & Old plasma & 7 & + & - & 0 & 0 \\
\hline $\begin{array}{l}3 \mathrm{a} . \\
\mathrm{b} .\end{array}$ & $\begin{array}{l}\text { Old plasma } \\
\text { Old plasma }\end{array}$ & $\begin{array}{l}8 \\
2\end{array}$ & $\begin{array}{l}+ \\
+\end{array}$ & $\overline{+}$ & $\begin{array}{l}\mathbf{0} \\
\mathbf{0}\end{array}$ & $\begin{array}{c}10.0 \S \\
0\end{array}$ \\
\hline 4. & Old plasma & 5 & + & + & 0 & 0 \\
\hline 5. & Ringer's solution & 16 & + & + & 10 & $\begin{array}{l}8.6 \|_{(6.9-10.7)} \\
\end{array}$ \\
\hline 6. & Inactive old plasma & 7 & + & + & 10 & $\begin{array}{l}8.0 \|_{(6.2-10.2)} \\
(6.0)\end{array}$ \\
\hline 7. & Inactive old plasma & 7 & + & + & 4 & $\begin{array}{l}3.6 \| \\
(2.6-5.1)\end{array}$ \\
\hline 8. & Inactive fresh plasma & 3 & + & + & 10 & $9.0 \|$ \\
\hline
\end{tabular}

* Refer to text for details.

† All samples equal to $10 \mathrm{ml}$.

$\ddagger$ Not performed.

Nonspecific antidiuretic activity, averaging $10.0 \mu \mathrm{U}$ per ml, completely resistant to thioglycolate inactivation. Mean and $95 \%$ confidence limits.

If Fresh plasma from two patients with diabetes insipidus and one hydrated normal subject. 

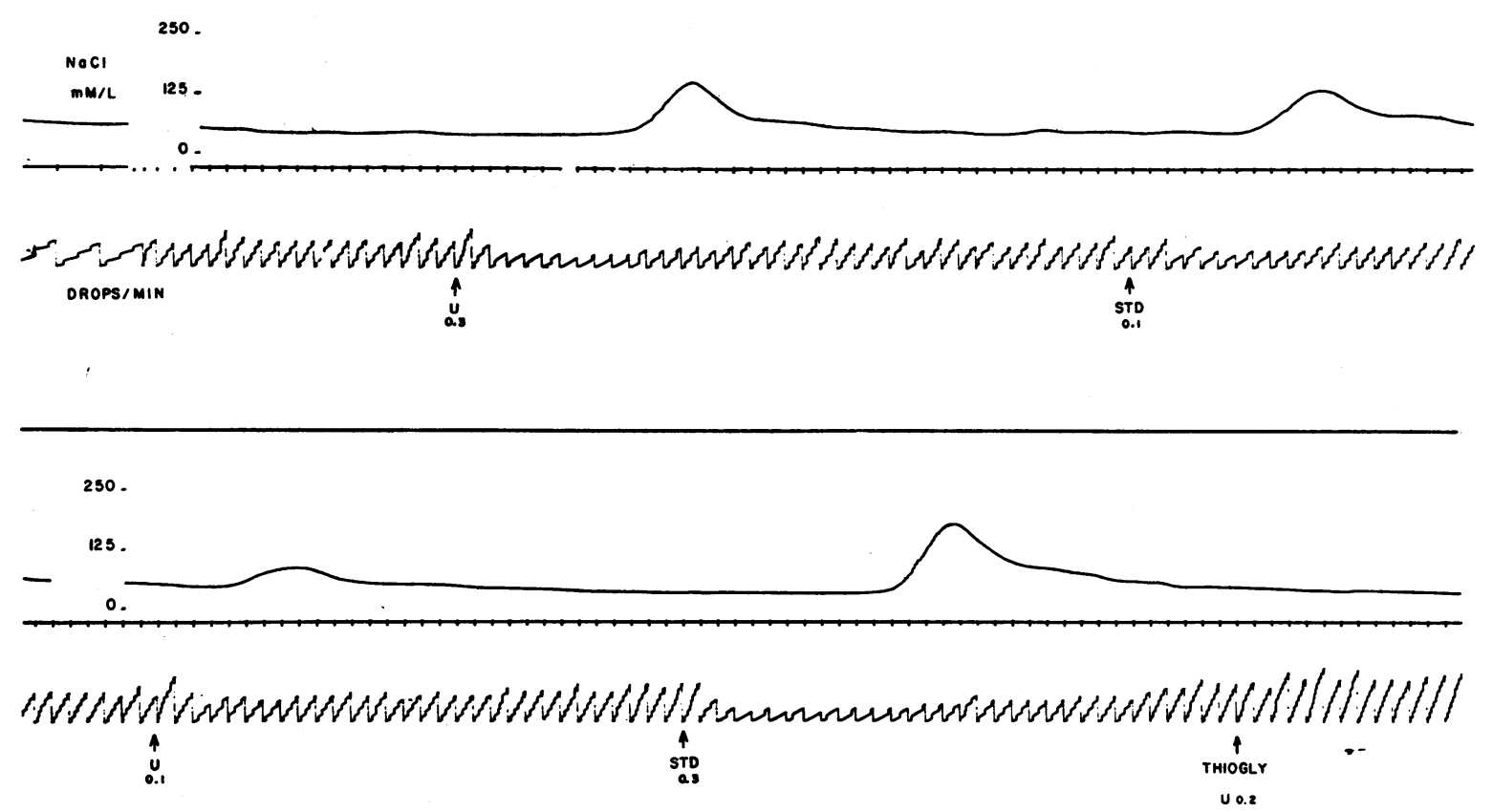

Fig. 2. Antidiuretic response of rat to standard and plasma AVP. Upper and lower panels represent a continuous study in one rat. Upper curve depicts urinary conductivity calibrated against standard $\mathrm{NaCl}$ solutions; lower curve shows urine flow recorded with an integrated drop counter in drops per minute. U $0.1,0.3=$ milliliters plasma extract equivalent to 1 and $3 \mathrm{ml}$ plasma. Std $0.1,0.3=5$ and $15 \mu \mathrm{U}$ AVP standard. Thiogly = thioglycolate treatment of $\mathrm{U} 0.2$.

antidiuretic factor effectively removed this substance (experiment $3 \mathrm{~b}$, Table II). Five other old plasma samples showed no nonspecific antidiuretic activity when taken through the entire column and paper chromatographic technic (experiment 4, Table II).

The presence of nonspecific antidiuretic activity in the column eluates of some old plasma samples prompted an evaluation of the presence of such activity in column eluates of fresh plasma. The column eluates of ten samples of fresh plasma from six subjects were lyophilized and dissolved in acidified Ringer's solution to equal a tenfold concentration of whole plasma. These solutions were assayed for antidiuretic activity before and after incubation with thioglycolate as described above. One patient with an inappropriate $\mathrm{ADH}$ syndrome had a total antidiuretic activity of the column eluate of $2.5 \mu \mathrm{U}$ per $\mathrm{ml}$ plasma in a sample obtained after hydration, and all activity was inactivated by thioglycolate. After nicotine administration, total activity rose to $9.9 \mu \mathrm{U}$ per ml, but $2.5 \mu \mathrm{U}$ was resistant to thioglycolate. One patient with Addison's disease had a total activity of the column eluate equal to $18.1 \mu \mathrm{U}$ per $\mathrm{ml}$ in dehydrated plasma. Thioglycolate inactivated $13.1 \mu \mathrm{U}$, but $5.0 \mu \mathrm{U}$ was resistant. By comparison this patient's plasma AVP by paper chromatography equaled $11.0 \mu \mathrm{U}$ per $\mathrm{ml}$ after hydration, which was completely inactivated by thioglycolate (see $\mathrm{Ta}$ ble IV, Patient 1).

A patient with pseudotumor cerebri in remission showed no antidiuretic activity in the column eluate of plasma obtained after water loading. After nicotine administration, total activity rose to $10.1 \mu \mathrm{U}$ per $\mathrm{ml}$, and all this material was inactivated by thioglycolate. However, after $3 \% \mathrm{NaCl}$ infusion, the column eluate had $49.4 \mu \mathrm{U}$ activity per $\mathrm{ml}$ plasma, and $7.5 \mu \mathrm{U}$ was resistant to thioglycolate inactivation. A patient with acromegaly, given nicotine, had $11.8 \mu \mathrm{U}$ activity per ml plasma in the column eluate, which was completely inactivated by thioglycolate. After paper chromatography of a portion of this column eluate, the AVP content equaled $9.6 \mu \mathrm{U}$ per ml plasma, and this too was completely inactivated by thiogly- 
colate. Two patients with diabetes insipidus showed no antidiuretic activity of column eluates of plasma samples obtained during random hydration, and in one subject there was also no activity observed in plasma obtained after nicotine administration.

Recovery of standard AVP. Recovery experiments with $10 \mu \mathrm{U}$ AVP standard per ml added to Ringer's solution or to inactive old plasma and taken through the entire procedure averaged 86 and $80 \%$, respectively (experiments 5 and 6 , Table II). Seven additional experiments with inactive old plasma containing $4 \mu \mathrm{U}$ AVP standard per $\mathrm{ml}$ showed an average recovery of $90 \%$ (experiment 7, Table II). The recovery of $10 \mu \mathrm{U}$ AVP standard per $\mathrm{ml}$ added to inactive fresh plasma from two patients with diabetes insipidus and one hydrated normal subject averaged $90 \%$ (experiment 8, Table II).

\section{Response of rat to standard and plasma AVP}

The changes in urine flow and conductivity of the diuretic rat after the injection of standard and plasma AVP are illustrated in a typical experiment in Figure 2. The similarity of the responses to standard and plasma AVP is readily apparent.

\section{Plasma AVP in normal subjects and patients with diabetes insipidus (Table III)}

The peripheral venous plasma concentration of AVP measured on 13 occasions in 10 normal subjects in the morning after overnight dehydration averaged $4.6 \mu \mathrm{U}$ per $\mathrm{ml}$ with a range of 2.5 to $10.0 \mu \mathrm{U}$ per $\mathrm{ml}$. In three normal subjects studied, plasma AVP was undetectable after water administration. In four normal subjects plasma AVP increased to between 14.5 and $35.2 \mu \mathrm{U}$ per $\mathrm{ml}$ after intravenous administration of hypertonic saline solution. Plasma AVP equaled $20.0 \mu \mathrm{U}$ per $\mathrm{ml}$ in one normal subject and rose to 32.0 and $52.0 \mu \mathrm{U}$ per $\mathrm{ml}$ on two separate occasions in another subject after nicotine stimulation of the neurohypophysis. Three other normal subjects who received nicotine in doses insufficient to produce significant pharmacological effects on the central nervous system showed only slight increases in plasma AVP to within the dehydrated normal range. Plasma AVP was not detectable in five patients with diabetes insipidus either in
TABLE III

Plasma AVP in normal subjects and patients with diabetes insipidus*

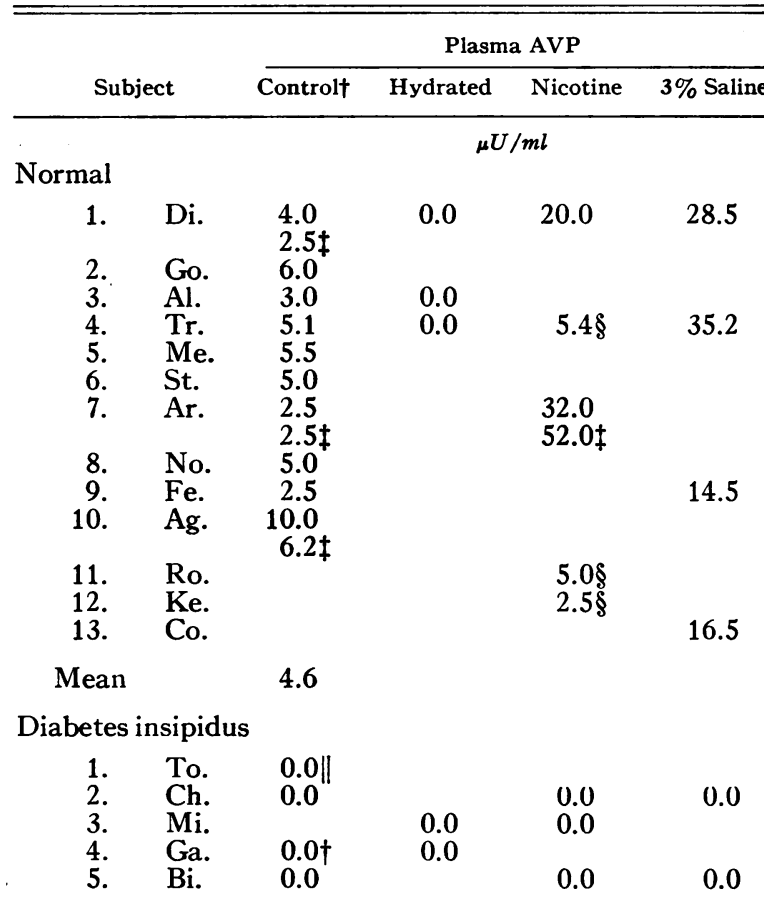

* The antidiuretic activity of all positive plasma samples was completely inactivated by thioglycolate.

† Overnight dehydration.

I Samples obtained on separate days.

\$Absence of pharmacological effects of nicotine.

\| The patients with diabetes insipidus were allowed water ad libitum before the control sample.

the randomly hydrated state or after nicotine or hypertonic saline administration (Table III).

\section{Plasma $A V P$ in patients with adrenocortical in- sufficiency}

Plasma AVP ranged from 13.1 to $100.0 \mu \mathrm{U}$ per $\mathrm{ml}$ in seven fasting glucosteroid-deficient patients (Table IV). These values greatly exceeded the normal range for similarly dehydrated normal subjects (Table III). Replicate assays of plasma AVP in two fasting untreated Addisonian patients showed consistently elevated levels (Table IV, Patients 2 and 3).

Two of the three patients with Addison's disease and all five of the hypopituitary subjects demonstrated subnormal diuretic responses to hydration typical of adrenocortical insufficiency (Table IV). Plasma AVP measured at 90 to 120 minutes after hydration was found to be within 
Plasma AVP and diuretic responses

\begin{tabular}{|c|c|c|c|c|c|c|c|}
\hline \multirow[b]{2}{*}{ No. } & \multirow[b]{2}{*}{ Age, Sex } & \multirow{2}{*}{\multicolumn{2}{|c|}{ Treatment }} & \multicolumn{2}{|c|}{ Controlf } & \multicolumn{2}{|c|}{ Hydrated 8} \\
\hline & & & & \multirow{2}{*}{$\begin{array}{l}\mathbf{P}_{\mathbf{A V P}} \\
\mu U / m l\end{array}$} & \multirow{2}{*}{$\begin{array}{c}\mathrm{P}_{\mathrm{osm}} \\
\mathrm{mOsm} / \mathrm{kg}\end{array}$} & \multirow{2}{*}{$\begin{array}{l}\mathrm{P}_{\mathrm{AVP}} \\
\mu U / m l\end{array}$} & \multirow{2}{*}{$\frac{\mathrm{P}_{\mathrm{osm}}}{m O s m / k g}$} \\
\hline Addison's dise & & $m g$ & hours & & & & \\
\hline 1. & $\begin{array}{l}\text { A.R. } \\
59 \mathrm{M}\end{array}$ & $\begin{array}{l}12.5 \mathrm{E} \\
100 \mathrm{E}\end{array}$ & $\begin{array}{r}-24 \\
-2\end{array}$ & 13.19 & $\underset{* *}{285}$ & $\begin{array}{r}11.0 \\
0.0\end{array}$ & $\begin{array}{l}275 \\
280\end{array}$ \\
\hline 2. & $\begin{array}{l}\text { J.D. } \\
48 \text { F }\end{array}$ & $\begin{array}{l}25 \mathrm{E} \\
12.5 \mathrm{E} \\
100 \mathrm{E}\end{array}$ & $\begin{array}{r}-24 \\
-48 \\
-3\end{array}$ & $\begin{array}{r}20.0 \\
39.6 \\
3.0\end{array}$ & $\begin{array}{l}* * \\
287 \\
290\end{array}$ & $\begin{array}{l}5.0 \\
0.0\end{array}$ & $\begin{array}{l}263 \\
272\end{array}$ \\
\hline 3. & $\begin{array}{l}\text { D.C. } \\
\text { 48 F }\end{array}$ & $\begin{array}{l}\text { 4MP } \\
4 M P \\
4 M P \\
100 E\end{array}$ & $\begin{array}{r}-48 \\
-24 \\
-24 \\
-2\end{array}$ & $\begin{array}{r}79.6 \\
60.0 \\
62.0 \\
4.5\end{array}$ & $\begin{array}{l}285 \\
291 \\
295 \\
284\end{array}$ & 2.0 & 283 \\
\hline \multicolumn{8}{|c|}{ Hypopituitarism } \\
\hline 4. & $\begin{array}{l}\text { V.C. } \\
62 \text { M }\end{array}$ & $\begin{array}{l}25 \mathrm{E} \\
100 \mathrm{E}\end{array}$ & $\begin{array}{r}-24 \\
-2\end{array}$ & $\begin{array}{r}100.0 \\
4.0\end{array}$ & $\begin{array}{l}296 \\
310\end{array}$ & $\begin{array}{r}60.7 \\
0.0\end{array}$ & $\begin{array}{l}289 \\
290\end{array}$ \\
\hline 5. & $\begin{array}{l}\text { C.P. } \\
45 \mathrm{~F}\end{array}$ & $\begin{array}{l}0 \\
25 \mathrm{E}\end{array}$ & -2 & $\begin{array}{r}14.6 \\
3.9\end{array}$ & $\begin{array}{l}294 \\
294\end{array}$ & $\begin{array}{l}8.6 \\
0.0\end{array}$ & $\begin{array}{l}278 \\
290\end{array}$ \\
\hline 6. & $\begin{array}{l}\text { C.B. } \\
61 \mathrm{~F}\end{array}$ & $\begin{array}{l}5 \mathrm{Pr} \dagger \dagger \\
5 \mathrm{Pr}\end{array}$ & $\begin{array}{r}-24 \\
-2\end{array}$ & $\begin{array}{l}30.0 \\
12.0\end{array}$ & $\begin{array}{l}304 \\
303\end{array}$ & $\begin{array}{r}15.0 \\
0.0\end{array}$ & $\begin{array}{l}288 \\
294\end{array}$ \\
\hline 7. & $\begin{array}{l}\text { H.G. } \\
62 \mathrm{M}\end{array}$ & $12.5 \mathrm{E} \ddagger$ & -48 & 40.0 & 280 & 40.0 & 279 \\
\hline 8. & $\begin{array}{l}\text { W.U. } \\
37 \mathrm{M}\end{array}$ & $\begin{array}{l}0 \\
100 \mathrm{E} \\
\text { EtOH }\end{array}$ & $\begin{array}{l}-3 \\
-1\end{array}$ & $\begin{array}{c}* * \\
29.9 \\
* *\end{array}$ & $\begin{array}{l}339 \\
304 \\
* *\end{array}$ & $\begin{array}{c}* * \\
15.0 \\
4.3\end{array}$ & $\begin{array}{l}327 \\
296 \\
317\end{array}$ \\
\hline
\end{tabular}

* $\mathrm{P}_{\mathrm{AVP}}$, plasma arginine vasopressin; $\mathrm{P}_{\text {osm }}$, plasma osmolality; $\mathrm{U}_{\text {osm }}$, urinary osmolality; $\mathrm{C}_{\mathrm{H}_{2} \mathrm{O}}$, free water clearance. $\dagger \mathrm{E}$, cortisone; MP, methyl prednisolone; $\mathrm{Pr}$, prednisone; EtOH, $90 \mathrm{ml}$ 86-proof bourbon whiskey; given at the designated interval before hydration.

$\mp$ After overnight dehydration and immediately before hydration.

$\$$ Ninety to 120 minutes after hydration.

$\|$ Hourly urine periods in Patients $1,2,3$, and 8 ; collections every half hour in Patients 4, 5, 6, and 7, with last half of each hourly period shown.

T Measured as thioglycolate sensitive activity of column eluate only.

** Not measured.

$\dagger$ One hundred $\mathrm{mg}$ hydrocortisone intravenously at $+2 \frac{1}{3}$ hours. See Figure 3.

¥ One hundred $\mathrm{mg}$ hydrocortisone intravenously at $+2 \frac{1}{4}$ hours. See Figure 4.

or above the "dehydrated" normal range in those patients with the abnormal water diuresis. The third Addisonian patient (Table IV, No. 3), who had demonstrated normal water diuresis in the absence of glucosteroid therapy on several occasions, showed an acute fall in plasma AVP from $62.0 \mu \mathrm{U}$ per ml before hydration to $2.0 \mu \mathrm{U}$ per $\mathrm{ml}$ at the peak of an essentially normal diuretic response.

In five dehydrated patients, oral administration of glucosteroids resulted in a sharp fall in plasma AVP levels to within or slightly above the dehydrated normal range within 2 to 3 hours of steroid therapy (Table V). The fall in plasma AVP with steroid therapy was not accompanied by significant alterations in renal function, except for a substantial increase in creatinine clearance in one patient. Plasma osmolality was essentially unchanged in three patients and significantly increased after steroid therapy in two.

Five patients treated with glucosteroids 2 to 3 hours before hydration demonstrated a normal diuretic response to the standard water test (Table IV, No. 1, 2, 4, 5, 6). In each instance plasma AVP fell to zero within 90 to 120 minutes of hydration, coincident with the maximal diuretic response.

The acute effect of intravenous hydrocortisone on plasma AVP and water diuresis in two hypopituitary patients is shown in Figures 3 and 4 . In 
TABLE IV

to hydration in hypoadrenal patients*

\begin{tabular}{|c|c|c|c|c|c|c|c|c|}
\hline \multicolumn{8}{|c|}{ Hours after hydration $\|$} & \multirow{2}{*}{$\begin{array}{c}\text { 4-hour } \\
\text { H:O } \\
\text { excretion }\end{array}$} \\
\hline$\overline{U_{\text {omm } 1}}$ & Сн20 & $U_{o s m 2}$ & $\mathrm{CH}_{20} \mathrm{O}$ & $U_{0 \operatorname{sem} 3}$ & $\mathrm{C}_{\mathrm{H} 2 \mathrm{O}}$ & $U_{0 \text { m } 4}$ & $\mathrm{C}_{2} \mathrm{O}$ & \\
\hline $\mathrm{mOsm} / \mathrm{kg}$ & $m l / m i n$ & $\mathrm{mOsm} / \mathrm{kg}$ & $m l / m i n$ & $\mathrm{mOsm} / \mathrm{kg}$ & $m l / m i n$ & $m O s m / k g$ & $\operatorname{mb} / \min$ & \\
\hline $\begin{array}{l}326 \\
469\end{array}$ & $\begin{array}{l}-0.4 \\
-1.4\end{array}$ & $\begin{array}{l}240 \\
140\end{array}$ & $\begin{array}{l}+0.6 \\
+4.0\end{array}$ & $\begin{array}{l}282 \\
143\end{array}$ & $\begin{array}{r}0.0 \\
+4.2\end{array}$ & $\begin{array}{l}308 \\
184\end{array}$ & $\begin{array}{l}-0.3 \\
+3.0\end{array}$ & $\begin{array}{r}43 \\
110\end{array}$ \\
\hline $\begin{array}{l}372 \\
432\end{array}$ & $\begin{array}{l}-0.6 \\
-1.2\end{array}$ & $\begin{array}{r}192 \\
78\end{array}$ & $\begin{array}{l}+0.8 \\
+3.7\end{array}$ & $\begin{array}{r}170 \\
82\end{array}$ & $\begin{array}{l}+1.2 \\
+4.7\end{array}$ & $\begin{array}{l}181 \\
184\end{array}$ & $\begin{array}{l}+0.8 \\
+0.5\end{array}$ & $\begin{array}{l}63 \\
88\end{array}$ \\
\hline 103 & +2.7 & 61 & +5.4 & 88 & +1.7 & 154 . & +0.7 & 76 \\
\hline $\begin{array}{l}562 \\
405\end{array}$ & $\begin{array}{l}-2.3 \\
-1.3\end{array}$ & $\begin{array}{l}391 \\
104\end{array}$ & $\begin{array}{l}-0.7 \\
+9.1\end{array}$ & $\begin{array}{r}347 \\
89\end{array}$ & $\begin{array}{l}-0.5 \\
+5.9\end{array}$ & $\begin{array}{l}339 \\
118\end{array}$ & $\begin{array}{r}-0.5 \\
+3.2\end{array}$ & $\begin{array}{r}40 \\
108\end{array}$ \\
\hline $\begin{array}{l}532 \\
146\end{array}$ & $\begin{array}{l}-0.6 \\
+3.0\end{array}$ & $\begin{array}{r}205 \\
85\end{array}$ & $\begin{array}{l}+0.7 \\
+5.8\end{array}$ & $\begin{array}{r}180 \\
86\end{array}$ & $\begin{array}{l}+0.9 \\
+6.3\end{array}$ & $\begin{array}{l}190 \\
130\end{array}$ & $\begin{array}{l}+0.8 \\
+2.5\end{array}$ & $\begin{array}{r}40 \\
132\end{array}$ \\
\hline $\begin{array}{l}305 \\
207\end{array}$ & $\begin{array}{r}0.0 \\
+0.7\end{array}$ & $\begin{array}{l}176 \\
150\end{array}$ & $\begin{array}{l}+1.1 \\
+3.0\end{array}$ & 161 & +1.8 & 178 & +1.4 & 95 \\
\hline 388 & -1.3 & 369 & -0.9 & & & & & \\
\hline $\begin{array}{l}178 \\
268 \\
157\end{array}$ & $\begin{array}{l}+1.1 \\
+0.2 \\
+1.4\end{array}$ & $\begin{array}{l}173 \\
273 \\
122\end{array}$ & $\begin{array}{l}+1.0 \\
+0.1 \\
+2.3\end{array}$ & $\begin{array}{l}237 \\
349 \\
158\end{array}$ & $\begin{array}{l}+0.3 \\
-0.4 \\
+1.3\end{array}$ & $\begin{array}{l}295 \\
365 \\
217\end{array}$ & $\begin{array}{l}+0.1 \\
-0.4 \\
+0.8\end{array}$ & $\begin{array}{l}34 \\
28 \\
46\end{array}$ \\
\hline
\end{tabular}

the absence of glucosteroid, water diuresis was subnormal in both patients, and plasma AVP was maintained at high levels despite plasma hypoosmolality and sustained overhydration. The intravenous administration of hydrocortisone produced a fall in plasma AVP to zero and a normal free water diuresis in both patients.

One patient (W.U., Table IV) had panhypopituitarism and blindness as an end result of prolonged intracranial hypertension associated with a pineal tumor that had been treated with $\mathrm{X}$ ray. Before the institution of glucosteroid therapy, he demonstrated a subnormal water diuresis typical of adrenocortical insufficiency; unfortunately, plasma AVP determinations were technically un- satisfactory during that study. However, plasma AVP in the fasting subject was found to be abnormally elevated 2 hours after $100 \mathrm{mg}$ oral cortisone and remained elevated during a second abnormal water test. A third water test in which $90 \mathrm{ml}$ 86-proof bourbon whiskey was administered before hydration resulted in a more substantial free water diuresis and a substantial fall in plasma AVP concentration to $4.3 \mu \mathrm{U}$ per $\mathrm{ml}$.

\section{Comparison of the present method with the direct} antidiuretic assay of whole human plasma

Experiments were performed to compare the antidiuretic activity of human plasma by the present method with the methods of Heller and 
TABLE V

Effect of glucosteroids on plasma AVP and renal function in dehydrated hypoadrenal patients*

\begin{tabular}{|c|c|c|c|c|c|c|c|c|c|}
\hline \multicolumn{2}{|r|}{ Patient } & \multicolumn{2}{|c|}{ Treatment $\dagger$} & \multirow{3}{*}{$\begin{array}{c}\text { AVP } \\
\mu U / m l \\
39.6 \\
3.0\end{array}$} & \multirow{3}{*}{$\begin{array}{c}P_{\text {osm }} \\
m \text { Osm } / k g \\
287 \\
290\end{array}$} & \multirow{3}{*}{$\begin{array}{c}\mathrm{U}_{\mathrm{osm}} \\
m O s m / k g \\
794 \\
822\end{array}$} & \multirow{3}{*}{$\begin{array}{l}\mathrm{C}_{\mathrm{H}} \mathrm{O} \\
m l / \min \\
-0.7 \\
-0.9\end{array}$} & \multirow{3}{*}{$\begin{array}{c}C_{\text {osm }} \\
m l / m i n \\
1.1 \\
1.3\end{array}$} & \multirow{3}{*}{$\begin{array}{c}\mathrm{Ca} \\
m l / m i n \\
40 \\
87\end{array}$} \\
\hline & & & hours & & & & & & \\
\hline 1. & J.D. $\ddagger$ Addison's & $\begin{array}{l}12.5 \mathrm{E} \\
100 \mathrm{E}\end{array}$ & $\begin{array}{r}-24 \\
-3\end{array}$ & & & & & & \\
\hline 2. & D.C. $\S$ Addison's & $\begin{array}{l}\text { 4MP } \\
100 \mathrm{E}\end{array}$ & $\begin{array}{r}-48 \\
-2\end{array}$ & $\begin{array}{r}79.6 \\
4.5\end{array}$ & $\begin{array}{l}285 \\
284\end{array}$ & $\begin{array}{l}524 \\
582\end{array}$ & $\begin{array}{l}-0.8 \\
-0.8\end{array}$ & $\begin{array}{l}1.8 \\
1.5\end{array}$ & $\|$ \\
\hline 3. & V.C.f Hypopituitarism & $\begin{array}{l}25 \mathrm{E} \\
100 \mathrm{E}\end{array}$ & $\begin{array}{r}-24 \\
-2\end{array}$ & $\begin{array}{r}100.0 \\
4.0\end{array}$ & $\begin{array}{l}296 \\
310\end{array}$ & $\begin{array}{l}572 \\
692\end{array}$ & $\begin{array}{l}-0.5 \\
-0.6\end{array}$ & $\begin{array}{l}1.0 \\
1.0\end{array}$ & $\begin{array}{l}55 \\
51\end{array}$ \\
\hline 4. & C.P. $\ddagger$ Hypopituitarism & $\begin{array}{l}0 \\
25 \mathrm{E}\end{array}$ & -2 & $\begin{array}{r}14.6 \\
3.9\end{array}$ & $\begin{array}{l}294 \\
294\end{array}$ & $\begin{array}{l}652 \\
589\end{array}$ & $\begin{array}{l}-0.2 \\
-0.5\end{array}$ & $\begin{array}{l}0.4 \\
1.1\end{array}$ & $\begin{array}{l}69 \\
68\end{array}$ \\
\hline 5. & C.B.f Hypopituitarism & $\begin{array}{l}5 \mathrm{Pr} \\
5 \mathrm{Pr}\end{array}$ & $\begin{array}{r}-24 \\
-2\end{array}$ & $\begin{array}{l}30.0 \\
12.0\end{array}$ & $\begin{array}{l}292 \\
303\end{array}$ & $\begin{array}{l}507 \\
487\end{array}$ & $\begin{array}{l}-0.7 \\
-0.5\end{array}$ & $\begin{array}{l}1.7 \\
0.8\end{array}$ & $\begin{array}{l}61 \\
59\end{array}$ \\
\hline
\end{tabular}

* Abbreviations as in Table IV; also, $\mathrm{C}_{\mathrm{ogm}}$, osmolar clearance, and $\mathrm{C}_{\mathrm{Cr}}$, creatinine clearance.

† See corresponding footnote to Table IV.

† Plasma and urine samples obtained on separate days after comparable periods of dehydration. Urinary data for 7 to 8 a.m. collection period.

\$ Urine samples collected from 6 to 8 a.m. and 8 to 10 a.m. during continuing dehydration from 10 p.m. the preceding evening; plasma samples obtained at 8 a.m. and 10 a.m. and $100 \mathrm{mg}$ cortisone administered orally at 8 a.m.

\| Not measured.

Stulc (16) and Czaczkes, Kleeman, and Koenig (17). Plasma was obtained in the morning from ten fasting subjects (four normal, three with Addison's disease, two with pineal tumors, and one hypophysectomized). One portion was extracted by the present method, and another portion was assayed immediately in the diuretic rat (16). A third sample was frozen by the addition of chips of solid carbon dioxide to the plasma according to the technique of Czaczkes, Kleeman, and

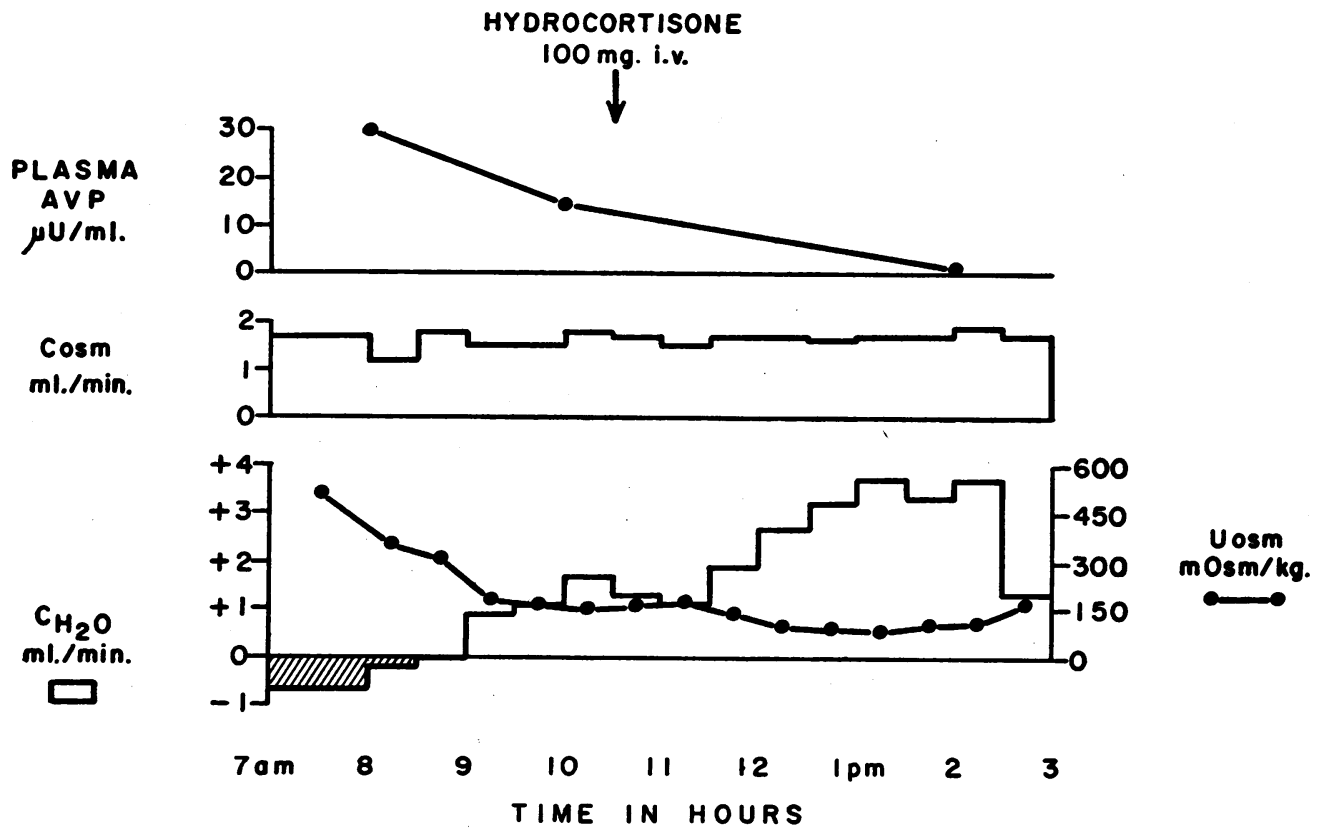

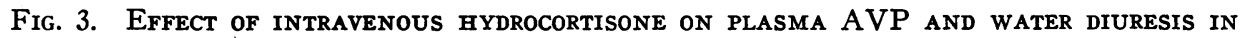
A patient with panhypopituitarism. Prednisone, $5 \mathrm{mg}$ by mouth 24 hours before study. Constant hydration of $20 \mathrm{ml}$ water per $\mathrm{kg}$ beginning at 8 a.m. after overnight dehydration. Plasma AVP was $30.0 \mu \mathrm{U}$ per $\mathrm{ml}$ at 8 a.m., $15.0 \mu \mathrm{U}$ per $\mathrm{ml}$ at 10 a.m., and $0.0 \mu \mathrm{U}$ per $\mathrm{ml}$ at 2 p.m. Cosm, osmolal clearance ; $\mathrm{C}_{\mathrm{H}_{2} \mathrm{O}}$, free water clearance; $\mathrm{U}_{\mathrm{osm}}$, urinary osmolality. 


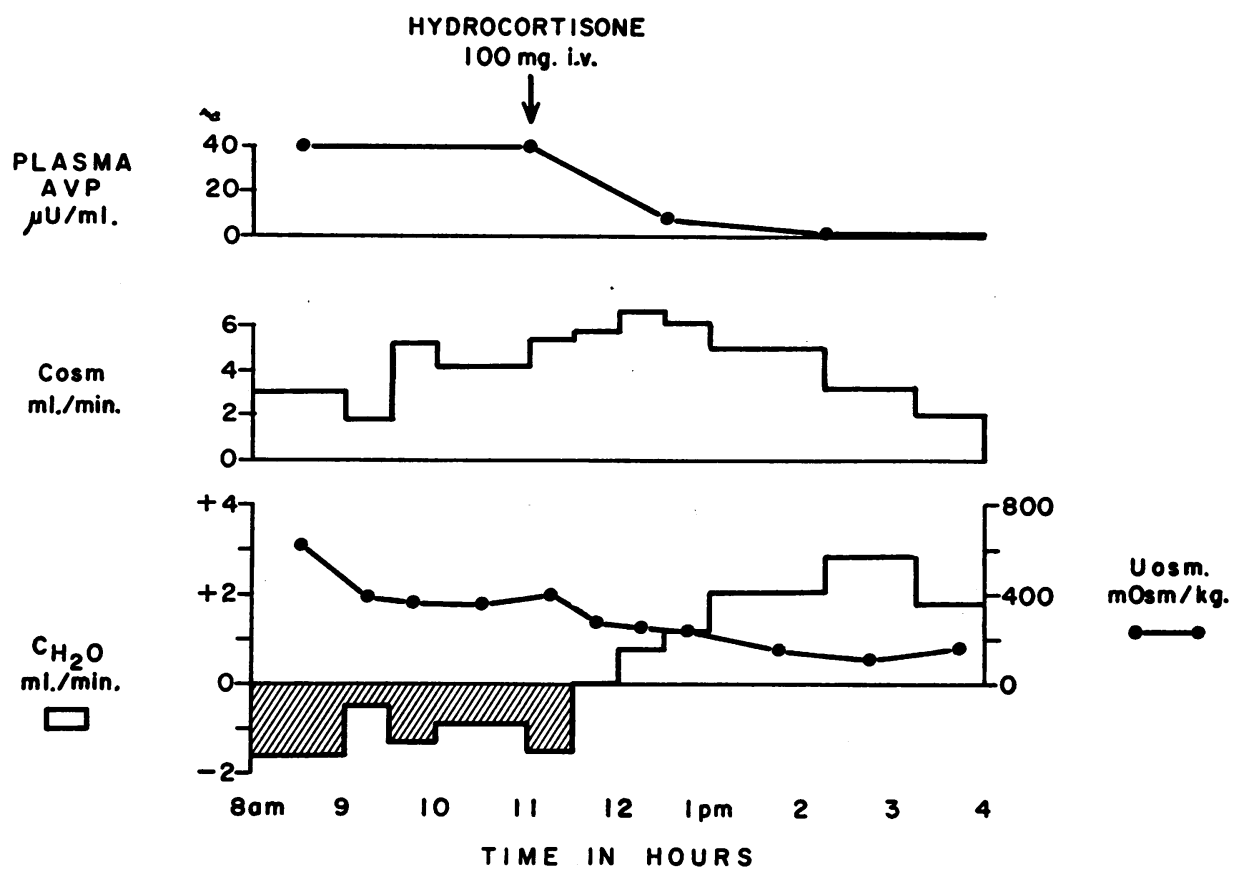

Fig. 4. EFFECT OF INTRAVENOUS HYDROCORTISONE ON PLASMA AVP AND WATER DIURESIS IN A PATIENT WITH CHROMOPHOBE ADENOMA AND HYPOPITUITARISM. Cortisone, $12.5 \mathrm{mg}$ by mouth 48 hours before study. Constant hydration of $20 \mathrm{ml}$ water per $\mathrm{kg}$ beginning at 8 a.m. after overnight dehydration. Plasma AVP was $40.0 \mu \mathrm{U}$ per $\mathrm{ml}$ at 8:20 a.m., $40.0 \mu \mathrm{U}$ per ml at $11: 10$ a.m., $9.7 \mu \mathrm{U}$ per $\mathrm{ml}$ at $12: 30$ p.m., and $0.0 \mu \mathrm{U}$ per $\mathrm{ml}$ at $2: 15$ p.m.

Koenig (17) and stored at $-20^{\circ} \mathrm{C}$. At a later date, this sample was thawed without using their technic of bubbling $\mathrm{CO}_{2}$ gas through the plasma during thawing and assayed immediately in a diuretic rat.

According to the present method, plasma AVP ranged from 3.0 to $6.0 \mu \mathrm{U}$ per $\mathrm{ml}$ in these normal subjects and from 13.1 to $100.0 \mu \mathrm{U}$ per $\mathrm{ml}$ in the patients. None of these plasma samples showed antidiuretic activity within the limits of the assay (less than $2 \mu \mathrm{U}$ per $\mathrm{ml}$ ) when as much as $1.0 \mathrm{ml}$ plasma was assayed immediately according to the technique of Heller and Stulc (16) or of Czaczkes, Kleeman, and Koenig (17). It should also be pointed out that in each plasma sample the antidiuretic activity was presumptively identified as AVP by thioglycolate inactivation, a technic not used by either of the foregoing groups to confirm the presence of a thiol-sensitive antidiuretic peptide.

\section{Discussion}

The present method for assay of AVP in human plasma utilizes the resin column fractionation technic of Weinstein, Berne, and Sachs (6) as modified by Yoshida, Motohashi, Ibayashi, and Okinaka (9) and additional purification of the column eluate by glass paper chromatography (18). In our hands, blank pyridine-acetate eluents of the resin columns (6) often showed significant antidiuretic activity that could not be inactivated by thioglycolate. The use of $50 \%$ acetic acid for elution of the resin (9) eliminated this nonspecific antidiuretic activity from reagents, which was probably contributed by the pyridine.

Our study has shown, however, that approximately one-half of the $50 \%$ acetic acid column eluates of old plasma and several column eluates of fresh plasma from diseased subjects contained nonspecific antidiuretic activity resistant to thioglycolate inactivation. This finding suggests that some human plasmas may contain TCA-soluble antidiuretic substances other than AVP that can introduce spurious results in those methods terminating with column chromatography $(6,9)$. The nature of the nonspecific antidiuretic activity of fresh plasma, which can be effectively separated from AVP by glass paper chromatography, has not been revealed by these preliminary studies in only a few patients. The extraction procedure 
itself could occasionally generate antidiuretic substances from plasma that are not AVP. The alternative possibility that antidiuretic factors other than AVP may be present in the circulation of some patients with disturbed water metabolism is extremely unlikely, since other plasma samples from the same subjects have failed to show such material.

This study has provided good evidence that the antidiuretic substance eluted from the paper chromatograms was, in fact, endogenous plasma AVP. The $R_{\mathbf{f}}$ of synthetic AVP as determined by a relatively specific staining reaction compared favorably with the distribution of biological activity on the chromatograms. Also, the endogenous antidiuretic activity of human plasma had the same $R_{f}$ as synthetic AVP on the paper chromatogram, and all recovered activity was sensitive to thioglycolate. Although this inactivation technic is not specific for AVP but is only indicative of a cystine-containing antidiuretic peptide, confirmation of this antidiuretic substance as AVP was indirectly substantiated by the absence of antidiuretic activity from the plasma of hydrated normal subjects and patients with diabetes insipidus.

The near quantitative recovery of physiological concentrations of AVP standard from inactive plasma samples attests to the precision, reproducibility, and sensitivity of this method. Although the bioassay method has a lower limit of sensitivity of about $2 \mu \mathrm{U}$ AVP, plasma concentrations as low as 0.2 to $0.4 \mu \mathrm{U}$ per ml could be reliably detected by assaying the equivalent of 5 to $10 \mathrm{ml}$ original plasma. Since this technic was routinely followed in this study, the discrepancy between our findings and the recent reports $(5,16,17)$ of lower plasma ADH levels in normal subjects and patients with adrenocortical insufficiency cannot be explained by differences in sensitivity of the bioassays.

This study has failed to confirm the $\mathrm{ADH}$ titers of human plasma reported by others $(5,16,17)$ using the direct bioassay of whole plasma; in our hands, plasma samples containing as much as $100 \mu \mathrm{U}$ AVP per $\mathrm{ml}$ were completely inactive by direct assay in rats sensitive to $2 \mu \mathrm{U}$ AVP. The explanation for these divergent results must await further experimentation.

This study demonstrates that patients with glucosteroid deficiency have increased plasma levels of AVP. Plasma AVP was sustained at high levels despite plasma dilution in those patients who showed the subnormal diuretic response to hydration typical of adrenocortical insufficiency. Steroid therapy lowered plasma AVP to within the normal range in dehydrated patients, and the normal diuretic response to hydration after steroid therapy was accompanied by a fall in circulating AVP to unmeasurable levels. The prompt reversal of the abnormal water diuresis by intravenous hydrocortisone was also associated with an abrupt fall in elevated plasma AVP levels to zero at the peak of maximal free-water diuresis.

These findings are entirely consistent with the hypothesis that sustained hypersecretion of AVP may be a major factor in the abnormal water metabolism of adrenocortical insufficiency and that glucosteroids correct the abnormal water diuresis by suppressing neurohypophyseal hyperfunction and restoring a normal neurohypophyseal response to plasma dilution (4). An additional finding of interest was that the kidney can excrete solute-free water, albeit at a subnormal rate, despite the presence of measurable levels of AVP in the circulation.

The effect of glucosteroids on AVP secretion during dehydration provides some insight into the mechanism by which steroids affect secretion of this neurohypophyseal hormone. This effect did not appear to be mediated via alterations in the tonicity or volume of the extracellular fluid compartment; plasma osmolality remained essentially unchanged, and there is little to support the view that the steroids could cause sufficient shift of fluid into the extracellular compartment to affect the volume regulation of AVP secretion. In a previous publication (4) it was shown that the glucosteroids inhibit the ADH-releasing action of nicotine, a drug that presumably stimulates the supraoptic neurones directly. More recently, it has been shown that steroids elevate the osmotic threshold for ADH release (19), a reflex that is probably also mediated via the supraoptic neurones. These findings permit a tentative hypothesis that the glucosteroids affect AVP:secretion by inhibiting the secretory activity of the supraoptic neurones.

The failure of cortisone to restore normal neurohypophyseal response to hemodilution in the patient with pinealoma was of unusual interest. 
Since this patient probably had extensive damage to neural structures in the region of the third and fourth ventricles as well as the hypothalamus, it is conceivable that his neurohypophyseal derangement was due to a disturbance in afferent neural pathways to the supraoptic nuclei. This observation provides some support for the concept that the glucosteroids act at the level of the supraoptic neurones and may be incapable of suppressing strong afferent neural stimuli to the neurohypophysis. The fact that ethyl alcohol inhibited AVP secretion to some degree suggests that alcohol may suppress the activity of higher neural centers controlling the supraoptic nuclei.

The increased levels of AVP in adrenally insufficient patients and the prompt decrease associated with steroid therapy could theoretically be attributed to steroid effects on the metabolism of AVP in hypoadrenal states rather than to direct effects of steroids on AVP release. Although we have not evaluated AVP metabolism in this report, the repeated demonstration $(3,20)$ that the action of vasopressin is not abnormally prolonged in adrenal insufficiency and not significantly altered by steroid therapy would make this explanation extremely improbable.

\section{Acknowledgments}

Dr. Dingman wishes to express sincere gratitude to Dr. George W. Thorn for the interest and encouragement he has shown toward this research endeavor over the years. We also wish to thank Dr. Akira Arimura for his initial contributions to this project.

\section{References}

1. Dingman, J. F., C. Gonzalez-Auvert, A. B. J. Ahmed, and A. Arimura. Plasma antidiuretic hormone in adrenal insufficiency (abstract). J. clin. Invest. 1965, 44, 1041.

2. Raisz, L. G., W. F. McNeely, L. Saxon, and J. D. Rosenbaum. The effects of cortisone and hydrocortisone on water diuresis and renal function in man. J. clin. Invest. 1957, 36, 767.

3. Kleeman, C. R., J. Koplowitz, M. H. Maxwell, R. Cutler, and J. T. Dowling. Mechanisms of impaired water excretion in adrenal and pituitary insufficiency. II. Interrelationships of adrenal cortical steroids and antidiuretic hormone in normal subjects and in diabetes insipidus. J. clin. Invest. 1960, 39, 1472.

4. Dingman, J. F., and R. Despointes. Adrenal steroid inhibition of vasopressin release from the neurohypophysis of normal subjects and patients with Addison's disease. J. clin. Invest. 1960, 39, 1851.
5. Kleeman, C. R., J. W. Czaczkes, and R. Cutler. Mechanisms of impaired water excretion in adrenal and pituitary insufficiency. IV. Antidiuretic hormone in primary and secondary adrenal insufficiency. J. clin. Invest. 1964, 43, 1641.

6. Weinstein, H., R. M. Berne, and H. Sachs. Vasopressin in blood: effect of hemorrhage. Endocrinology $1960,66,712$.

7. Arimura, A., and J. F. Dingman. Unpublished observations.

8. Hirs, C. H. W., S. Moore, and W. H. Stein. Isolation of amino acids by chromatography on ion exchange columns: use of volatile buffers. J. biol. Chem. 1952, 195, 669.

9. Yoshida, S., K. Motohashi, H. Ibayashi, and S. Okinaka. Method for the assay of antidiuretic hormone in plasma with a note on the antidiuretic titer of human plasma. J. Lab. clin. Med. 1963, 62, 279.

10. Dieckert, J. W., W. B. Carney, R. L. Ory, and D. J. Morris. A simplified technic for the preparation of glass paper impregnated with silicic acid. Analyt. Chem. 1958, 30, 1442.

11. Staub, M. C., and J. F. Dingman. Rapid method for determination of aldosterone in human urine by glass paper chromatography. J. clin. Endocr. 1961, $21,148$.

12. Sawyer, W. H. Biologic assays for oxytocin and vasopressin in Methods in Medical Research, J. H. Quastel, Ed. Chicago, Year Book, vol. 9, 1961, p. 210.

13. U. S. Pharmacopeial Convention. The Pharmacopeia of the United States of America, 16th ed. Easton, Pa., Mack, 1960, p. 794.

14. Dingman, J. F., K. Benirschke, and G. W. Thorn. Studies of neurohypophyseal function in man. I. Diabetes insipidus and psychogenic polydipsia. Amer. J. Med. 1957, 23, 226.

15. Bonsnes, R. W., and H. H. Taussky. On the colorimetric determination of creatinine by the Jaffe reaction. J. biol. Chem. 1945, 158, 581 .

16. Heller, J., and J. Stulc. The physiology of the antidiuretic hormone. II. The antidiuretic activity of normal human plasma. Physiol. bohemoslov. 1960, 9, 5.

17. Czaczkes, J. W., C. R. Kleeman, and M. Koenig. Physiologic studies of antidiuretic hormone by its direct measurement in human plasma. J. clin. Invest. $1964,43,1625$.

18. Arimura, A., and J. F. Dingman. Specific and sensitive assay method for vasopressin and oxytocin using glass-paper chromatography. Nature (Lond.) 1959, 184, 1874.

19. Aubry, R. H., H. R. Nankin, A. M. Moses, and D. H. P. Streeten. Measurement of the osmotic threshold for vasopressin release in human subjects, and its modification by cortisol. J. clin. Endocr. 1965, 25, 1481.

20. Lindeman, R. D., H. C. Van Buren, and L. G. Raisz. Effect of steroids on water diuresis and vasopressin sensitivity. J. clin. Invest. 1961, 40, 152. 